JRPB, Vol. 7, No. 1, Maret 2019, Hal. 75-84

DOI: $10.29303 /$ jrpb.v7i1.107

ISSN 2301-8119, e-ISSN 2443-1354

Tersedia online di http://jrpb.unram.ac.id/

\title{
MODIFIKASI ASPEK RASIO SUDU KINCIR ANGIN DAN GEAR RASIO PADA AERATOR BEBASIS TEKNOLOGI POMPA SPIRAL BERTENAGA AIR
}

\author{
Modification of Windmills Propeller Aspect Ratio and Gear Ratios on Water Powered Spiral \\ Pump Technology Based Aerators
}

\section{Gunomo Djoyowasito ${ }^{1, *)}$, Rifaldi Aprilianto1, Ary Mustofa Ahmad ${ }^{1}$, Musthofa Lutfi ${ }^{1}$}

\author{
${ }^{1}$ Jurusan Keteknikan Pertanian, Fakultas Teknologi Pertanian, Universitas Brawijaya, \\ Jl. Veteran, Malang 65145
}

Email*): Djoyowasitogunomo@yahoo.com

Diterima: Januari 2019

Disetujui: Maret 2019

\begin{abstract}
Productivity of shrimp farm in Indonesia can be enhanced by maintaining quality of water using aerator. This research aims to increase rotation velocity through aerator modification utilizing spiral pump that moved by a wind turbine. The research method was conducted by several steps, i.e. (1) construction of modification design of aspect ratio and gear ratio, (2) preparation of wind turbine material, (3) assembly of tool, and (4) test performance. Modification was applied in the velocity requirement of aerator with aspect of wind turbine ratio and gear ratio. The aspect ratio used on the wind turbine propeller were 0.833 and 2.167, whereas the gear ratio used were 1:10 and 1:5. Measured parameter were wind velocity, aerator performance (wind turbine velocity, spiral pump velocity, power, discharge, and head), and water quality (dissolved oxygen). The result of the performance test showed the wind velocity ranged from $0.62-4.65 \mathrm{~m} / \mathrm{s}$. The measured theoretical rotational velocity was 45.4632. While the value of rotational reduction was approximately 0.41. The lowest power was obtained by the lowest wind velocity of $0.62 \mathrm{~m} / \mathrm{s}$. Generated power was 0.1967 Watt. Furthermore, the value of power, water discharge, and head were approximately 24.02834 watt, $15.52008 \mathrm{~cm}^{3} / \mathrm{s}, 30.16 \mathrm{~cm}$ respectively. While the dissolved oxygen was $4.4-11.9 \mathrm{mg} / \mathrm{L}$. Aerator using 0.833 aspect ratio and 1:10 gear ratio similar with aerator using 2.167 aspect ratio and 1:5 gear ratio can produce better rotational velocity, power, and water discharge. However, the unmodified aerator head produced higher value. Whereas, both aerator can produce dissolved oxygen of $4-11 \mathrm{mg} / \mathrm{L}$.
\end{abstract}

Keywords: aerator, aspect ratio, gear ratio, spiral pump, savonius

\begin{abstract}
ABSTRAK
Peningkatan produktivitas tambak udang di Indonesia dilakukan dengan tetap menjaga kualitas air tambak menggunakan aerator. Penelitian ini bertujuan untuk meningkatkan kecepatan putar dengan modifikasi aerator yang memanfaatkan teknologi pompa spiral yang kemudian digerakkan oleh kincir angin. Metode penelitian dilakukan dengan beberapa tahapan, yaitu: (1)
\end{abstract}


Pembuatan rancangan modifikasi aspek rasio dan gear rasio (2) Persiapan Komponen kincir angin dan gear rasio, (3) Perakitan alat, (4) Uji kinerja alat. Modifikasi dilakukan pada kebutuhan kecepatan putar aerator dengan aspek rasio kincir angin dan gear rasio. Aspek rasio yang digunakan pada sudu kincir angin sebesar 0,833 dan 2,167, sementara gear rasio yang digunakan adalah 1:10 dan 1:5. Parameter yang diukur adalah kecepatan angin, kinerja aerator (kecepatan putar kincir angin, kecepatan putar pompa spiral, daya, debit, tinggi tekan), dan kualitas air (oksigen terlarut). Hasil uji kinerja alat dengan kecepatan angin berkisar antara 0,62 - 4,65 m/s. Kecepatan putar teoritis yang terukur adalah sebesar 45,4632. Sementara untuk reduksi putar memiliki nilai rata-rata sebesar 0,41. Daya teoritis terkecil yang dihasilkan oleh kecepatan angin terkecil, yaitu sebesar 0,62 m/s. Daya yang dihasilkan sebesar 0,1967 Watt. Kemudian daya, debit air, dan tinggi tekan rata-rata 24,02834 watt, $15.52008 \mathrm{~cm}^{3} / \mathrm{s}, 30,16 \mathrm{~cm}$. Sementara oksigen terlarut yang dihasilkan berkisar antara 4,4-11,9 mg/L. Aerator dengan aspek rasio 0,833 dan gear rasio 1:10 serta aerator dengan aspek rasio 2,167 dan gear rasio 1:5 mampu menghasilkan kecepatan putar, daya, dan debit air yang lebih baik. Namun, untuk tinggi tekan aerator yang belum dimodifikasi menghasilkan nilai yang lebih tinggi. Sementara kedua aerator mampu menghasilkan oksigen terlarut berkisar $4-11 \mathrm{mg} / \mathrm{L}$.

Kata kunci: aerator, aspek rasio, gear rasio, pompa spiral, savonius

\section{PENDAHULUAN}

Tambak merupakan suatu wadah yang dapat digunakan untuk budidaya ikan, rumput laut, rajungan, kepiting, udang, dan hewan lainnya yang dapat hidup di air payau (Ismayani, 2017). Salah satu tambak yang memiliki potensi hasil yang baik adalah tambak udang, dimana berdasarkan data FAO (2015) dalam Hakim (2017) di Indonesia sendiri telah banyak melakukan ekspor komoditi udang yang membuat Indonesia berada posisi kedua penghasil udang terbesar selama kurun waktu 2004 - 2013 dengan jumlah 13.147.297 ton. Permasalahan utama yang sering ditemukan dalam kegagalan produksi tambak udang adalah buruknya kualitas air selama masa pemeliharaan (Arsad, dkk., 2017). Kualitas air ini sangat dipengaruhi oleh oksigen terlarut yang merupakan kebutuhan dasar kehidupan organisme didalam air (Salmin, 2005). Kekurangan oksigen dapat menyebakan organisme mudah tertular penyakit, stress, menghambat pertumbuhan, dan dapat menyebabkan kematian sehingga menurunkan produktivitasnya (Kordi dan Tacung, 2007). Upaya yang dilakukan untuk mengatasi permasalahan ini para petani tambak udang menggunakan aerator sebagai sistem aerasi. Dimana pada umumnya masyarakat menggunakan tenaga diesel atau tenaga listrik untuk menggerakkan aerator seperti pada aerator tipe kincir air (Utama, dkk., 2013).

Berdasarkan permasalahan tersebut maka dibuat aerator yang memanfaatkan teknologi pompa spiral yang merupakan pompa yang sederhana yang dapat digerakkan oleh arus air, sungai, dan angin (Kassab et al., 2005). Untuk menggerakkan aerator ini dimanfaatkan energi angin yang melimpah dengan memanfaatkan teknologi kincir angin Savonius Tipe-U yang mampu berputar pada kecepatan angin rendah (Latif, 2013). Dimana untuk menghubungkan putaran kincir angin dan putaran poma spiral maka digunakan differential gear dengan rasio gear tertentu. Namun penggunaan pompa spiral membutuhkan kecepatan putar yang tinggi (Marwanto dan Asral, 2017). Sehingga dilakukan modifikasi aspek rasio sudu kincir angin dan gear rasio untuk meningkatkan kecepatan putar yang dihasilkan kincir angin sebagai penggerak pompa spiral. Dimana dengan kecepatan putar pompa spiral yang meningkat diharapkan pompa spiral mampu melakukan proses aerasi yang lebih maksimal. 


\section{METODE PENELITIAN}

\section{Alat}

Beberapa alat yang digunakan dalam perancangan, yaitu las listrik dan karbit, roller, cutting, gerinda, kunci L dan kunci pas. Sementara alat yang digunakan untuk pengujian, yaitu windmeter digital, tachometer, DO meter, rollmeter, gelas ukur, wadah penampung.

\section{Bahan}

Bahan yang digunakan dalam penelitian ini antara lain plat galvalum sebagai bahan dalam pembuatan kincir angin, plat strip sebagai bahan kerangka kincir angin, besi as 2,54 cm sebagai poros kincir angin, mur, baut dan rivet sebagai pengunci alat, air tambak sebagai media perlakuan, kayu, terpal, untuk membuat sekatan pada tambak sebagai kolam penelitian air tambak, Aquades sebagai bahan untuk kalibrasi DO meter.

\section{Metode}

Penelitian ini dilakukan pada bulan Juni - Juli 2018, dengan beberapa tahapan yaitu: (1) Pembuatan rancangan modifikasi aspek rasio, dan gear rasio (2) Persiapan Komponen kincir angin dan gear rasio, (3) Perakitan alat, (5) Uji kinerja alat. Desain dari keseluruhan aerator pompa spiral dapat dilihat pada gambar 1.

Sementara desain modifikasi aspek rasio sudu kincir angin dan gear rasio dapat dilihat pada gambar 2. Dimana modifikasi dilakukan dengan menambah tinggi sudu kincir angin sebesar $75 \mathrm{~cm}$ dan mengganti gear driver dengan roda gigi bediameter $7,5 \mathrm{~cm}$.
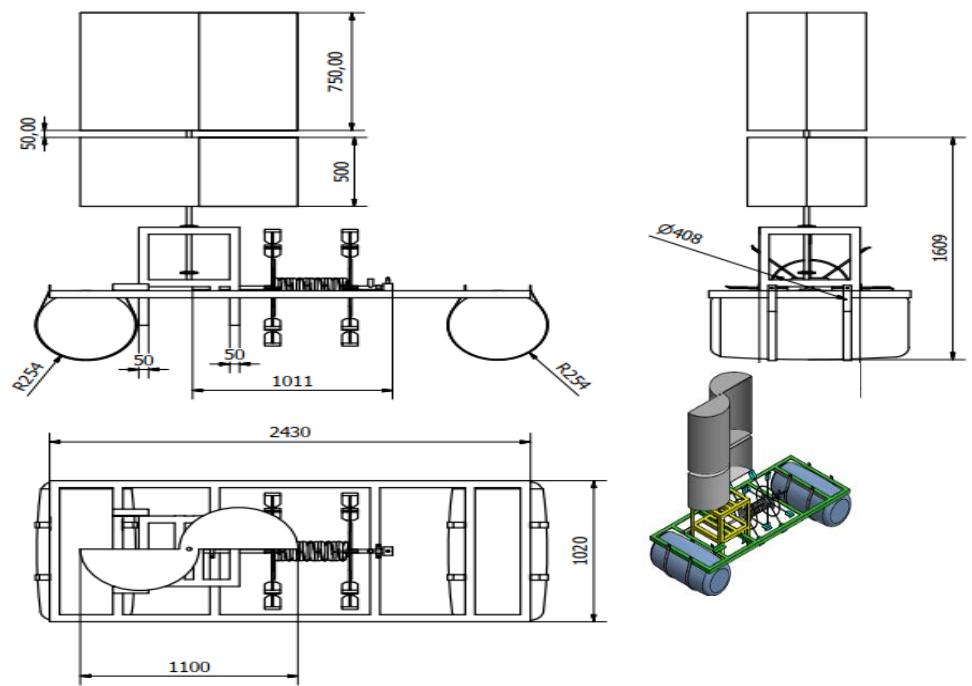

Gambar 1. Rancangan Aerator Pompa Spiral
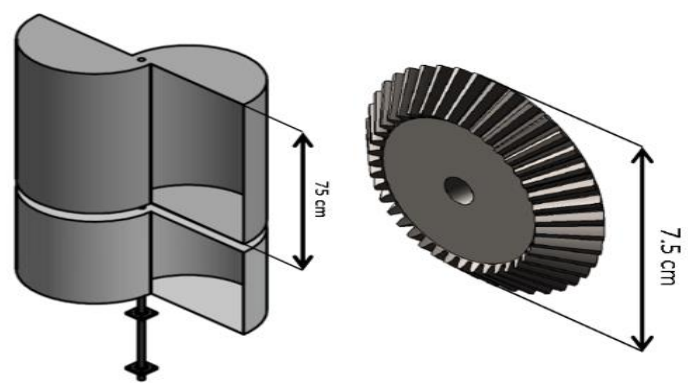

Gambar 2. Desain Rancangan Modifikasi Aspek rasio sudu kincir angin dan roda gigi 
Pengujian pada penelitian ini dilakukan untuk menguji kelayakan alat hasil modifikasi sehingga bisa berfungsi dengan baik. Pengujian ini dilakukan selama 5 hari berturut-turut. Dimana setiap harinya dilakukan dari pukul 08.00 - 20.00 dengan selang waktu pengukuran yaitu 3 jam.

1. Kecepatan angin

Kecepatan angin diukur dengan windmeter.

2. Kecepatan putar teoritis (rpm)

Kecepatan putar teoritis dihitung dengan rumus

$$
\mathrm{N}_{\mathrm{T}}=\left(\left(\frac{v}{D \times \pi}\right) \times 60\right) \text {. }
$$

3. Reduksi putar turbin

Reduksi putar turbin dihitung dengan rumus

$\mathrm{N}_{\mathrm{A}}=\mathrm{N}_{\mathrm{T}}$ x Red atau Red $=\mathrm{N}_{\mathrm{A}} / \mathrm{N}_{\mathrm{T}} \ldots$ (2)

Dimana $\mathrm{N}_{\mathrm{A}}$ adalah kecepatan putar aktual yang diukur dengan tachometer.

4. Daya angin teoritis (watt)

Daya angin teoritis dihitung dengan rumus

$$
\mathrm{P}_{\mathrm{T}}=0.5 \times \rho \times(\mathrm{D} \times \mathrm{t} 1) \times \mathrm{v}^{3} .
$$

5. Daya angin aktual (watt)

Daya angin aktual dihitung dengan rumus

$\mathrm{P}_{\mathrm{A}}=\mathrm{P}_{\mathrm{T}} \times$ Eff atau $\mathrm{P}_{\mathrm{A}}=2 \pi n$

Asumsi: Menurut Park (1981), efisiensi maksimal yang dapat dihasilkan oleh kincir angin savonius adalah sekitar $59,3 \%$.

6. Debit air

Debit air dapat dihitung dengan rumus $\mathrm{Q}=\frac{V}{t 2}$

7. Oksigen terlarut (DO)

Kandungan oksigen terlarut diukur dengan menggunakan DO meter.

\section{HASIL DAN PEMBAHASAN}

\section{Rancang Bangun Alat}

Proses pembuatan alat dilakukan perencanaan desain alat yang menggunakan software Autocad 2010. Perancangan model aerator tambak pompa spiral bertenaga air ini dilakukan dengan pendekatan struktural dan fungsional. Rancangan struktural digunakan untuk mengetahui komponen dan dimensi secara detail dari setiap komponen tersebut pada model yang dibuat. Rancangan fungsional digunakan untuk mengetahui fungsi dari setiap komponen model alat. Hasil penerapan dari rancangan model yang dibuat dapat dilihat pada gambar $3 \mathrm{di}$ bawah ini.

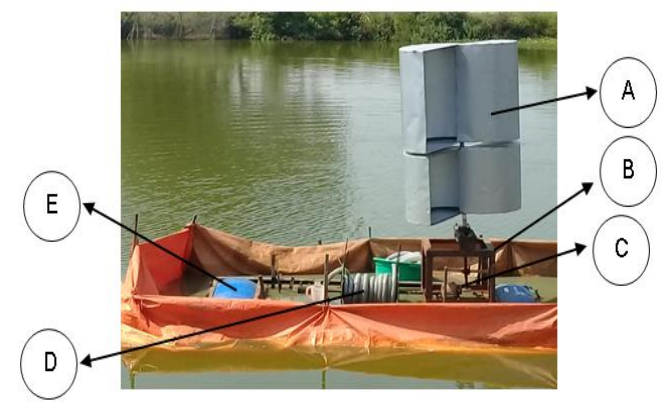

Gambar 3. Hasil Rancangan Aerator Pompa Spiral

Bagian dan fungsi alat sebagai berikut: (A) Kincir angin sebagai penggerak, (B) Kerangka penyangga sebagai penyangga alat, (C) Differential gear sebagai transmisi, (D) Pompa spiral untuk pengaerasi air tambak, (E) Pelampung untuk mengapungkan alat.

\section{Hasil Modifikasi Alat}

Modifikasi dilakukan pada bagian kincir angin yang ditambahkan aspek rasio sudunya yaitu perbandingan tinggi dan diameter sudu dan differential gear dimana dilakukan penggantian rasio gearnya. Hasil rancangan dapat dilihat pada gambar 4 dan gambar 5 . 


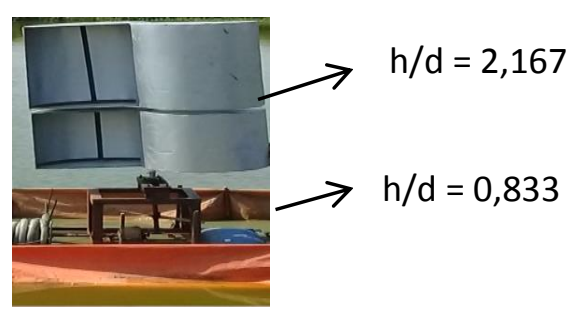

Gambar 4. Hasil Modifikasi Aspek Rasio Sudu Kincir Angin

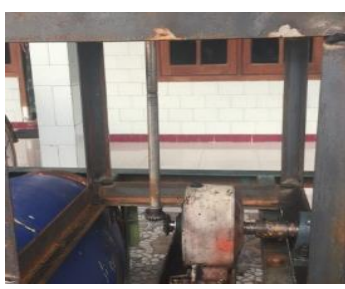

Gear rasio 1: 10

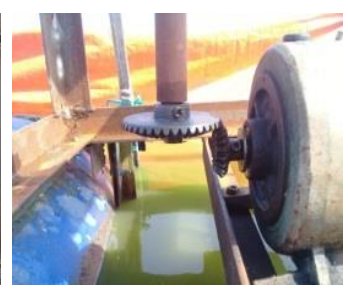

Gear rasio 1: 5
Gambar 5. Hasil Modifikasi Gear Rasio

Hasil modifikasi aspek rasio sudu yang dilakukan berfungsi untuk meningkatkan kecepatan putar kincir angin, hal ini dikarenakan pada kincir angin savonius semakin besar perbedaan aspek rasio sudu (h/d) maka semakin besar kecepatan putar yang dihasilkan (Brusca et. al., 2014). Hasil Modifikasi pada differential gear dengan gear rasio 1:5 ini berfungsi untuk meningkatkan kecepatan putar pompa spiral, Hal ini dikarenakan semakin kecil rasio gear yang digunakan akan semakin besar torsi yang dibutuhkan dan semakin bertambah kecepatan yang dihasilkan (Yunianto, 2016).

\section{Hasil Pengukuran Potensi Angin}

Hasil pengukuran potensi angin dilakukan selama 5 hari berturut-turut. Dari hasil pengukuran tersebut, dapat diketahui bahwa besarnya potensi angin yang tersedia di wilayah tambak Desa Wedani - Cerme berkisar antara 0,62 $4,65 \mathrm{~m} / \mathrm{s}$ dengan kecepatan angin rata-rata yang diperoleh sebesar $2,6172 \mathrm{~m} / \mathrm{s}$. Dari hasil pengukuran kecepatan angin setiap harinya, dapat diketahui bahwa kondisi angin di wilayah tambak tersebut tidak selalu sama kondisi tersebut dapat dilihat pada gambar 6. Sementara dari pengukuran yang dilakukan setiap 3 jam dari pukul 08.00-20.00 WIB dapat dilihat bahwa nilai maksimum rata - rata kecepatan angin selalu terjadi pada pukul 14.00 yaitu sebesar $4.266 \mathrm{~m} / \mathrm{s}$ dan nilai minimum rata - rata kecepatan angin selalu terjadi pada pikul 08.00 WIB yaitu sebesar 1,588 $\mathrm{m} / \mathrm{s}$. Kondisi ini dapat dilihat pada gambar 7 .

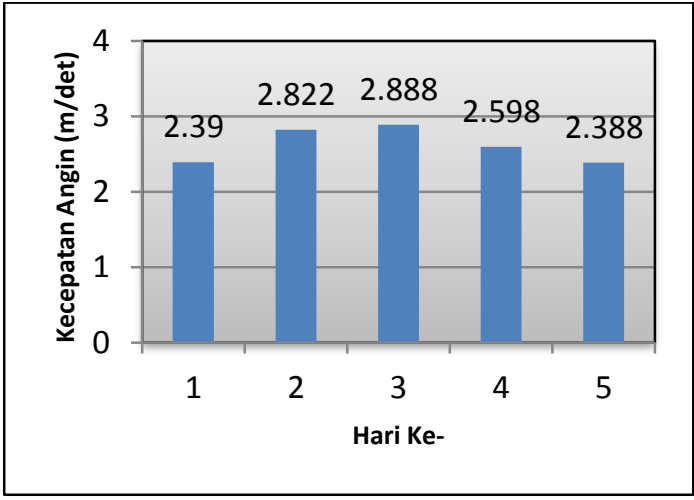

Gambar 6. Grafik rata - rata kecepatan angin dan hari pengamatan

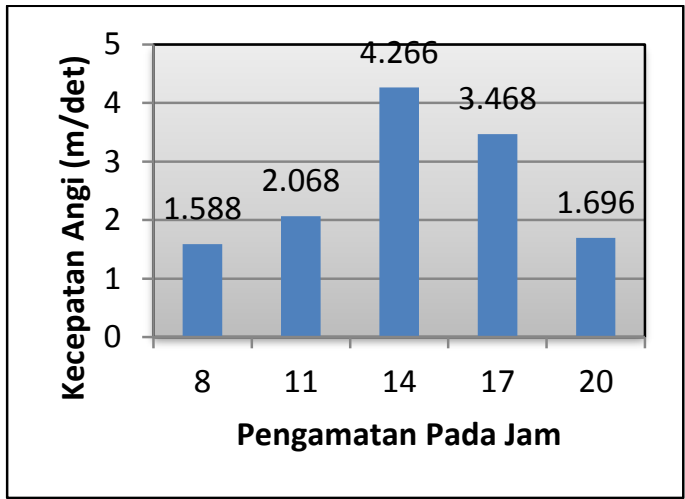

Gambar 7. Grafik rata - rata kecepatan angin dan waktu pengamatan

Perbedaan kecepatan angin ini terjadi disebabkan oleh adanya perbedaan tekanan. Menurut Kartasapoetra (2004) di dalam Pramono, dkk., (2016) daerah yang memiliki tekanan rendah memiliki suhu yang lebih tinggi dibandingkan daerah yang memiliki tekanan tinggi

\section{Jumlah Putaran (rpm)}

Berdasarkan pengukuran kecepatan putar kincir angin dan pompa spiral dapat diketahui bahwa kincir angin pada aerator 
pompa spiral yang telah dimodifikasi mampu berputar pada kecepatan angin minimal $1,51 \mathrm{~m} / \mathrm{s}$. Sementara kecepatan putar kincir angin yang dihasilkan berkisar antara $2-62 \mathrm{rpm}$, sementara kecepatan putar pompa spiral berkisar antara $0,4-$ $12,4 \mathrm{rpm}$. Dimana dari data yang diperoleh dapat dibuat grafik seperti pada gambar 8 .

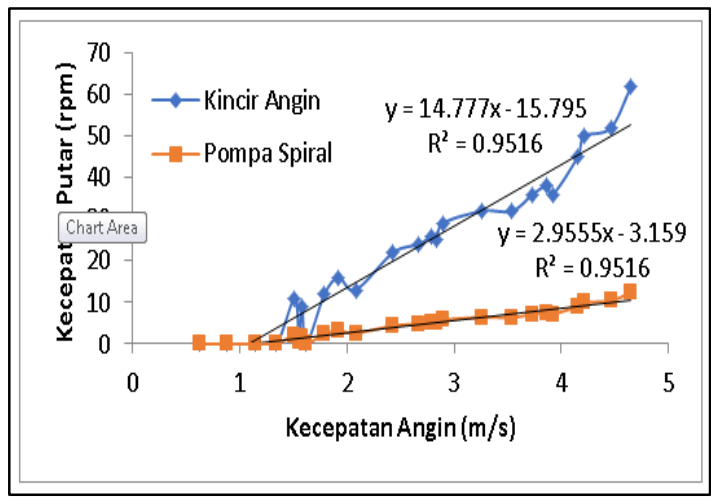

Gambar 8. Grafik Hubungan Kecepatan Angin dengan Kecepatan Putar Turbin Masing - Masing Aerator

Berdasarkan gambar 8 dapat dilihat bahwa semakin besar nilai kecepatan angina, semakin bertambah juga nilai kecepatan putar kincir angin dan pompa spiral. Sehingga dapat diketahui bahwa kecepatan angin dan besar rotasi dihasilkan memiliki hubungan yaitu berbanding lurus. Berdasarkan hal tersebut, hasil ini telah sesuai dengan penelitian yang dilakukan oleh Aryanto, dkk., (2013), yaitu kecepatan angin berbanding lurus dengan putaran yang dihasilkan.

\section{Kecepatan Putar Teoritis dan Reduksi Putar Turbin}

Berdasarkan penelitian yang telah dilakukan menunjukkan bahwa rata - rata kecepatan putar teoritis yang terukur adalah sebesar 45,4632. Sementara untuk reduksi putar memiliki nilai rata - rata sebesar 0,41. Kemudian nilai kecepatan putar teoritis terbesar terjadi pada hari ke 4 pukul 14.00 yaitu sebesar 80,776. Sementara nilai terkecil kecepatan putar teoritis terjadi pada hari pertama pukul 08.00 yaitu sebesar 10,77. Sementara untuk nilai reduksi putaran kincir angin terbesar terjadi pada hari ke 4 pukul 14.00 yaitu sebesar 0,77 .

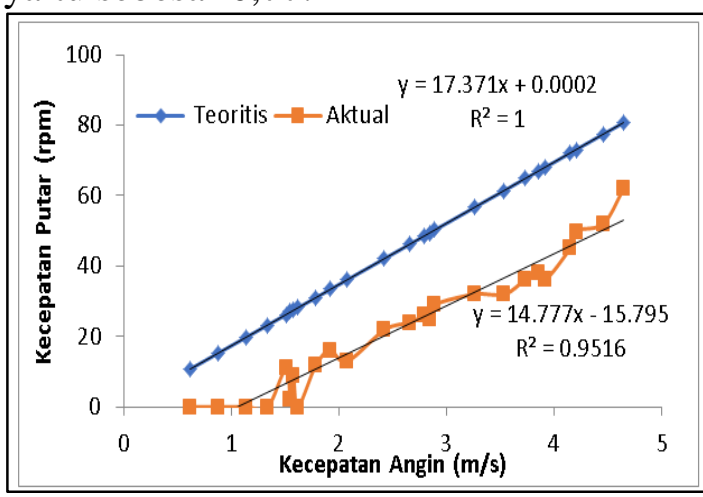

Gambar 9. Grafik Hubungan Kecepatan Angin Dengan Kecepatan Putar Teoritis dan Aktual

Berdasarkan gambar 9 dapat dilihat bahwa nilai kecepatan putar teoritis terus bertambah seiring dengan bertambahnya nilai kecepatan angin. Sementara nilai kecepatan putar aktual juga memiliki nilai yang bertambah seiring bertambahnya nilai kecepatan angin, namun untuk beberapa data dapat dilihat bahwa nilai kecepatan putar aktual kincir angin ada yang mengalami penurunan dengan bertambahnya nilai kecepatan angin. Kecepatan putar aktual dipengaruhi oleh kondisi pompa spiral yang berisi air yang membuat berat putaran kincir angin. Beban differential gear dan arah angin yang tidak searah dengan putaran kincir angin.

\section{Daya Angin Teoritis dan Daya Angin Aktual}

Berdasarkan perhitungan yang dilakukan dengan persamaan 4 dan 5 didapatkan nilai daya teoritis terkecil yang dihasilkan oleh kecepatan angin terkecil, yaitu sebesar $0,62 \mathrm{~m} / \mathrm{s}$ daya yang dihasilkan sebesar 0,1967 Watt. Sementara untuk nilai kecepatan angin terbesar, yaitu sebesar 4,65 m/s, daya yang dihasilkan sebesar 82,949 Watt. 
Sementara daya aktual terkecil adalah 0,117 watt, dan nilai daya aktual terbesar adalah 49,189 Watt.

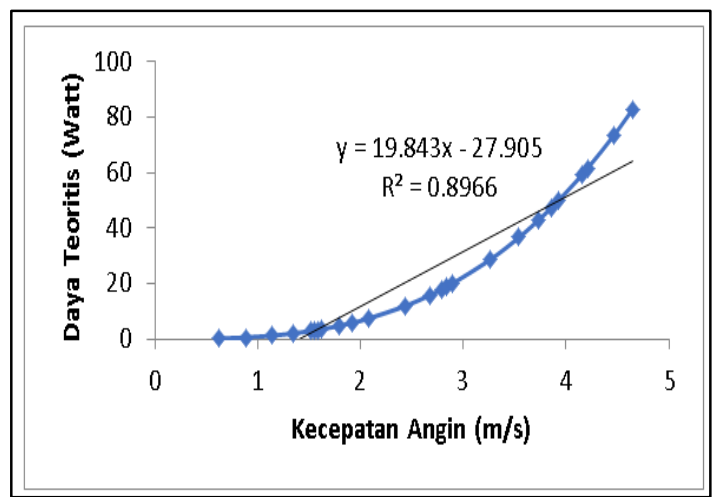

Gambar 10. Grafik Hubungan Kecepatan Angin Dan Daya

Berdasarkan gambar 10 dapat dilihat bahwa nilai daya yang dihasilkan oleh kincir angin semakin bertambah seiring bertambahnya nilai kecepatan angin. Sehingga dapat disimpulkan bahwa nilai daya dan kecepatan angin adalah berbanding lurus. Kesimpulan tersebut telah sesuai dengan penelitian yang telah dilakukan oleh Nanang, dkk., (2016) bahwa semakin besar kecepatan angin maka akan semakin besar daya yang dihasilkan.

\section{Debit Air dan Tinggi Tekan}

Berdasarkan data yang didapatkan dapat dilihat bahwa nilai rata - rata kecepatan angin 2,6172 m/s. dari kecepatan angin tersebut dapat menghasilkan rata - rata debit aliran sebesar $15,52008 \mathrm{~cm}^{3} / \mathrm{s}$ dan tinggi tekan rata - rata sebesar $30,16 \mathrm{~cm}$. Kemudian pada kecepatan angin minimal yang mampu memutar kincir angin dan pompa spiral sebesar $1,51 \mathrm{~m} / \mathrm{s}$, dimana dengan kecepatan angin tersebut dapat dihasilkan kecepatan putar turbin dan pompa spiral sebesar 11 dan 2,2 rpm yang kemudian menghasilkan debit air sebesar 2,667 $\mathrm{cm}^{3} / \mathrm{s}$, dan tinggi tekan sebesar $9 \mathrm{~cm}$. Sedangkan untuk kecepatan angin maksimal yakni sebesar 4,65 m/s mampu untuk menghasilkan kecepatan putar turbin dan pompa spiral sebesar 62 dan $12,4 \mathrm{rpm}$ yang kemudian menghasilkan debit aliran sebesar $38 \mathrm{~cm}^{3} / \mathrm{s}$ dengan tinggi tekan sebesar $83 \mathrm{~cm}$.

Berdasarkan gambar 11 dan gambar 12 dapat dilihat bahwa seiring bertambahnya nilai kecepatan putar pompa spiral nilai debit air dan tinggi tekan juga mengalami kenaikan. Sehingga dapat disimpulkan bahwa hubungan kecepatan putar pompa spiral dengan debit air dan tinggi tekan adalah berbanding lurus. Kondisi ini sesuai dengan penelitian yang dilakukan oleh Marwanto dan Asral (2017) dimana semakin cepat pompa spiral berputar maka akan semakin besar debit air yang dihasilkan.

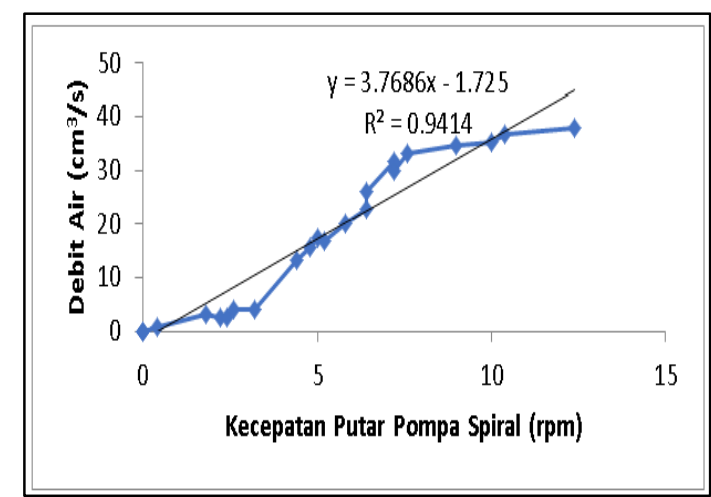

Gambar 11. Grafik Hubungan Kecepatan Putar Pompa Spiral Dan Debit Air

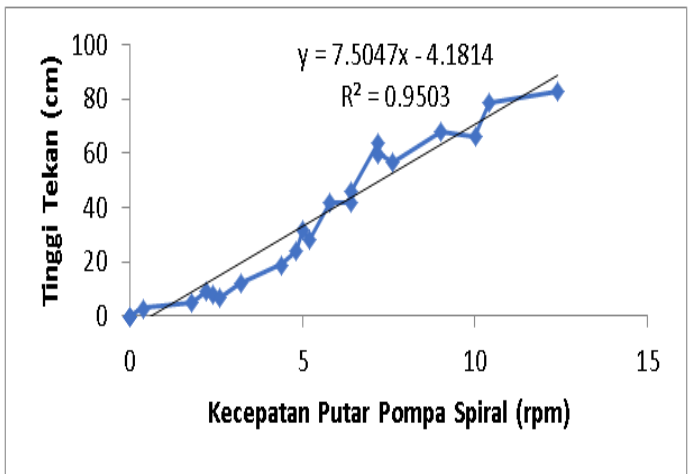

Gambar 12 Grafik Hubungan Kecepatan Putar Pompa Spiral Dan Tinggi Tekan

\section{Oksigen Terlarut (Disolved Oxygen)}

Berdasarkan data yang didapatkan nilai oksigen terlarut yang ada di tambak 
Desa Wedani berkisar antara 4,4 - 11,9 $\mathrm{mg} / \mathrm{L}$ dengan rata - rata sebesar 8,016 $\mathrm{mg} / \mathrm{L}$. Nilai oksigen terlarut maksimum terjadi pada hari ke 3 pukul 17.00 . sementara nilai oksigen terlarut terjadi pada hari pertama pukul 08.00.

Tabel 1. Nilai rata - rata oksigen terlarut pada waktu pengamatan yang berbeda pada aerator yang telah dimodifikasi

\begin{tabular}{cccc}
\hline & & \multicolumn{2}{c}{$\begin{array}{c}\text { Oksigen Terlarut } \\
(\mathrm{mg} / \mathrm{L})\end{array}$} \\
\cline { 3 - 4 } Jam ke & $\begin{array}{c}\text { Kec. Angin } \\
(\mathrm{m} / \mathrm{det})\end{array}$ & $\begin{array}{c}\text { Sebelu } \\
\mathrm{m}\end{array}$ & $\begin{array}{c}\text { Sesuda } \\
\mathrm{h}\end{array}$ \\
\hline 8.00 & 1.588 & 5.44 & 5.44 \\
11.00 & 2.068 & 5.44 & 7.1 \\
14.00 & 4.266 & 7.1 & 9.8 \\
17.00 & 3.468 & 9.8 & 10.82 \\
20.00 & 1.696 & 10.82 & 6.92 \\
\hline Rata - & 2.6172 & 7.72 & 8.016 \\
Rata & & & \\
\hline
\end{tabular}

Berdasarkan tabel 1, nilai oksigen terlarut terbesar rata - rata terjadi pada pukul 17.00 dan oksigen terlarut terjadi pada pukul 08.00 pagi. Selain itu dapat dilihat pula bahwa rata - rata oksigen terlarut mengalami peningkatan seiring waktu pengukuran atau pengoperasian aerator. Dimana dari pukul 08.00 - 17.00 oksigen mengalami peningkatan sementara pada pukul $17.00-20.00$ oksigen terlarut mengalami penurunan. Penurunan yang terjadi pada malam hari disebabkan oleh aerator yang sudah tidak dapat bekerja optimal karena menurunnya kecepatan angin, kemudian karena sudah tidak adanya fotosintesis, dan oksigen yang yang kemudian digunakan oleh semua organisme yang hidup didalam tambak maupun disekitar tambak sepanjang malam. hal ini sesuai dengan penelitian yang dilakukan oleh (Sinaga, dkk., 2016).

\section{Perbandingan Alat yang Telah Dimodifikasi dan Belum Dimodifikasi}

Berdasarkan tabel 2 dapat dilihat bahwa pada aerator pompa spiral yang telah dimodifikasi mengalami peningkatan kinerja. Dimana pada kecepatan angin yang sama nilai kecepatan putar kincir angin, pompa spiral, daya dan debit air memiliki nilai yang lebih tinggi. Namun untuk tinggi tekan yang dihasilkan aerator yang telah dimodifikasi memiliki nilai yang lebih rendah yang disebabkan adanya penyumbatan pada nozel oleh lumpur.

Tabel 2 Tabel perbandingan aerator belum modifikasi dan telah di modifikasi

\begin{tabular}{clcc}
\hline No. & \multicolumn{1}{c}{ Pembanding } & Belum Modifikasi & Telah Dimodifikasi \\
\hline 1 & Kecapatan angin & $0,45-6,71 \mathrm{~m} / \mathrm{s}$ & $0,62-4,65 \mathrm{~m} / \mathrm{s}$ \\
& & & \\
2 & Kecepatan angin terendah untuk & $2,5 \mathrm{~m} / \mathrm{s}$ & $1,51 \mathrm{~m} / \mathrm{s}$ \\
& memutar kincir angin & $22-64 \mathrm{rpm}$ & $2-62 \mathrm{rpm}$ \\
3 & Kecepatan putar kincir angin & $2,2-6,4 \mathrm{rpm}$ & $0,4-12,4 \mathrm{rpm}$ \\
4 & Kec. Putar pompa spiral & $0,03-81,73 \mathrm{watt}$ & $0,197-82,94 \mathrm{watt}$ \\
5 & Daya & $7-18,33 \mathrm{~cm}^{3} / \mathrm{s}$ & $0,667-38 \mathrm{~cm}^{3} / \mathrm{s}$ \\
6 & Debit air & $42-118 \mathrm{~cm}$ & $3-83 \mathrm{~cm}$ \\
7 & Tinggi tekan & $4,5-11,1 \mathrm{mg} / \mathrm{L}$ & $4,4-11,9 \mathrm{mg} / \mathrm{L}$ \\
8 & Oksigen terlarut & & \\
\hline
\end{tabular}

Kemudian kecepatan angin minimum yang mampu menggerakkan kincir angin pada aerator yang dimodifikasi berada pada kecepatan angin yang lebih rendah yaitu 1,51. $\mathrm{m} / \mathrm{s}$
Sementara oksigen terlarut yang dihasilkan memiliki range yang hampir sama dan merupakan kondisi oksigen terlarut yang sesuai dengan yang dibutuhkan spesies udang yaitu $4-11$ 
mg/L. Menurut Ferreira, et al. (2011) konsentrasi minimal DO (oksigen terlarut) yang dibutuhkan spesies udang agar dapat bertahan hidup adalah sebesar 4-6 mg/L, sedangkan kandungan DO yang optimal bagi udang berkisar antara $7-11 \mathrm{mg} / \mathrm{L}$.

\section{KESIMPULAN}

Berdasarkan hasil pengujian dan penelitian aerator pompa spiral bertenaga bayu yang telah dimodifikasi dapat di simpulkan bahwa:

1. Kecepatan angin yang terukur adalah antara 0,62-4,65 m/s.

2. Kecepatan angin minimum yang mampu menggerakkan kincir angin adalah $1,51 \mathrm{~m} / \mathrm{s}$.

3. Kecepatan putar teoritis yang terukur adalah sebesar 45,4632. Sementara untuk reduksi putar memiliki nilai rata - rata sebesar 0,41. Daya teoritis terkecil yang dihasilkan oleh kecepatan angin terkecil yaitu sebesar $0,62 \mathrm{~m} / \mathrm{s}$ daya yang dihasilkan sebesar 0,1967 Watt.

4. Pada kecepatan angin yang sama nilai kecepatan putar kincir angin, pompa spiral, daya dan debit air memiliki nilai yang lebih tinggi. Namun untuk tinggi tekan yang dihasilkan aerator yang telah dimodifikasi memiliki nilai yang lebih rendah. Oksigen terlarut yang dihasilkan berkisar antara 4,4 $11,9 \mathrm{mg} / \mathrm{L}$

\section{DAFTAR PUSTAKA}

Arsad, Sulastri, Afandy, Ahmad, Atika P. Purwadhi, Maya, Betrina V., Saputra, Dhira K., dan Buwono, Nanik Retno. (2017). Studi Kegiatan Budidaya Pembesaran Udang Vaname (Litopenaeus Vannamei) dengan Penerapan Sistem Pemeliharaan Berbeda. Jurnal Ilmiah Perikanan dan Kelautan, 9(1). ISSN: 2085-5842
Aryanto, Firman, Mara, I Made, dan Nuarsa, Made. (2013). Pengaruh Kecepatan Angin Dan Variasi Jumlah Sudu Terhadap Unjuk Kerja Turbin Angin Poros Horizontal. Jurnal Dinamika Teknik Mesin, 3(1). ISSN: 2088-088X.

Brusca, S., Lanzafame, R., Messina, M., (2014). Design of A Vertical-Axis Wind Turbine: How The Aspect Ratio Affects The Turbine's Performance. International Journal of Energy and Environmental Engineering. Vol. 5. Pp. 333 - 340

Ferreira, N.C, C. Bonnetti, and W.Q. Seiffert. (2011). Hydrological and Water Quality Indices as Management Tools in Marine Shrimp Culture. Aquaculture 318: 425-433

Hakim, Luqman. 2017. Performa Budidaya udang vename (Litopenaeus Vannamei) Semi Intensif di Desa Purworejo Kecamatan Pasir Sakti Kabupaten Lampung Timur. Skripsi. Lampung: Universitas Lampung

Ismayani, Erika. 2017. Manajemen Usaha Budidaya Udang Vanname (Litopeneaus Vannamei) (Studi Kasus Tambak Pt. Beroro Jaya Vanname Di Kabupaten Konawe Selatan). Tesis. Kendari: Universitas Halu Oleo 2017

Kassab, Sadek Z, A. A.A Naby, and El Sayed I.A.B. (2005). Coil Pump Performance Under Variable Operating Conditions. Ninth International Water Technology Conference, IWTC9.

Kordi, M.G.H.K., dan Tacung, A.B. (2007). Pengelolaan Kualitas Air Dalam Budidaya Perairan. Jakarta: PT Rineka Cipta.

Latif, Melda. (2013). Efisiensi Prototipe Turbin Savonius pada Kecepatan Angin Rendah. Jurnal Rekayasa Elektrika, 10(3). 
Marwanto, dan Asral. (2017). Pengujian Pompa Spiral Dengan Kincir Air Pada Aliran Irigasi. Jurnal Teknik, 4(2).

Nanang, Rahmat, Gunarto, dan Sarwon, Eko. (2016). Study Eksperimental Berbagai Macam Jenis Sudu Turbin Angin Sumbu Horisontal Skala Laboratorium. Respository UM Pontianak. Diakses pada 30 juli 2018.

http://repository.unmuhpnk.ac.id/id/ eprint/149.

Park, J. 1981. The Wind Power Book. California: Chesire Book

Pramono, Yuri, Warsito, dan Syafriadi. (2016). Monitoring Data Kecepatan Dan Arah Angin Secara Real Time Melalui Web. Jurnal Teori Dan Aplikasi Fisika, 4(02).

Salmin. (2005). Oksigen Terlarut (DO) dan Kebutuhan Oksigen Biologi (BOD) sebagai Salah Satu Indikator untuk Menentukan Kualitas Perairan. Oseana XXX(3): 21-26.

Sinaga, Eva Lia Risky, Muhtadi, Ahmad, dan Bakti, Darma. (2016). Profil
Suh Oksigen Terlarut dan $\mathrm{pH}$ Secara Vertikal Selama 24 Jam di Danau Kelapa Gading Kabupaten Asahan Sumatera Utara. Omni-Akuatika, 12(2), November 2016: 114 -12.

Utama, Aditya Rifa, Mubarrok, Muhammad Fasih, Ardiansyah, Antomi, Hendra, Fathoni, Muhammad Januar, dan Dikairono, Rudy. (2013). Eco Aerator: Inovasi Penyuplai Oksigen Dengan Teknologi Vertical Axis Wind Dan Archimedes' Screw Guna Menurunkan Biaya Operasional Petani Tambak. e-Proceeding PIMNAS. Surabaya: Institut Teknologi Sepuluh Nopember Surabaya.

Yunianto, Rizky Firmansyah. (2016). Analisa Pengaruh Variasi Perbandingan Roda Gigi Transmisi Untuk Memaksimalkan Daya Listrik Pada Turbin Angin Savonius Bertingkat. Skripsi. Malang: Universitas Islam Malang. 